\title{
Wybrane determinanty jakości funkcjonowania przedsiębiorstw społecznych
}

\section{Agnieszka Perzyńska}

\author{
Uniwersytet Zielonogórski \\ E-mail:a.perzynska@wez.uz.zgora.pl \\ ORCID: 0000-0003-1801-0701
}

\author{
Katarzyna Wolak \\ Uniwersytet Zielonogórski \\ E-mail: kasia2157@onet.pl \\ ORCID: 0000-0002-6224-7995
}

\author{
Magdalena Zaraś \\ Uniwersytet Zielonogórski \\ E-mail:magdalena.d.zaras@gmail.com \\ ORCID: 0000-0002-9070-1219
}

Publikacja sfinansowana przez: Małopolska Wyższa Szkoła Ekonomiczna w Tarnowie

Korespondencja:

Agnieszka Perzyńska

Uniwersytet Zielonogórski,

ul. Podgórna 50 budynek A-0

65-246 Zielona Góra

E-mail: a.perzynska@wez.uz.zgora.pl

\begin{abstract}
Abstrakt: Celem artykułu jest prezentacja wybranych praktyk zarządzania zasobami ludzkimi w przedsiębiorstwach społecznych. W publikacji opisano sukces społecznego przedsiębiorcy, kontekstowe uwarunkowania osiągania sukcesu przedsiębiorstw społecznych oraz typologie czynników decydujących o sukcesie przedsiębiorstw społecznych. Zarządzanie zasobami ludzkimi w przedsiębiorstwie społecznym jest procesem złożonym, względem którego ciągle brak jest wyczerpującej wiedzy i wypracowanych, w pełni sprawdzonych narzędzi. W opracowaniu dokonano charakterystyki specyfiki zarządzania przedsiębiorstwem społecznym. Uzupełnienia artykułu dokonuje opis zarządzania zasobami ludzkimi i praktyki zarządzania zasobami ludzkimi w przedsiębiorstwach społecznych. Możliwości, które daje właściwe zarządzanie zasobami ludzkimi, stwarza warunki do skutecznego zarządzania przedsiębiorstwem przy wyznaczonej misji oraz określonych celach strategicznych firmy. Z całą pewnością można stwierdzić, że organizacje społeczne, które opracowują ambitne i wartościowe strategie, podchodzą z należytą starannością do każdego z elementów procesu zarządzania zasobami ludzkimi. Ostatnią z poruszonych kwestii w tym artykule jest charakterystyka kompetencji przedsiębiorcy społecznego, gdzie znajomość kompetencji wymaganych do zarządzania przedsiębiorstwem społecznym jest atutem każdej organizacji.
\end{abstract}

Słowa kluczowe: zarządzanie, zarządzanie zasobami ludzkimi, zaangażowanie

\section{Wprowadzenie}

Każde przedsiębiorstwo zarówno społeczne, jak i komercyjne prowadząc działalność uzależnia swoje efektywne funkcjonowanie od wielu czynników. Jednym $\mathrm{z}$ nich jest właściwe wykorzystanie podstawowego czynnika, jakim 
jest czynnik pracy ludzkiej. Odpowiedni proces zarządzania zasobami ludzkimi wpływa na przewagę konkurencyjną $\mathrm{w}$ sposobie funkcjonowania organizacji $\mathrm{w}$ warunkach istniejącej konkurencji, jak i minimalizowanie kosztów z tym funkcjonowaniem związanych. Oprócz zasobów ludzkich każde przedsiębiorstwo posiada zasoby materialne, finansowe oraz informacyjne, jednak odpowiednie zarządzanie zasobami ludzkimi rozumianymi jako ogół pracowników zatrudnionych w danej jednostce organizacyjnej, wpływa na decyzje wykorzystania pozostałych czynników i oczywiście na sukces organizacji. Celem artykułu jest ukazanie priorytetów, które są kluczowe dla osiągnięcia powodzenia działalności organizacji społecznych. Przedstawione zostaną najważniejsze czynniki pozwalające przedsiębiorcy odnieść sukces, koncentrując się przede wszystkim na udowodnieniu, że kluczem sukcesu jest zaangażowanie.

\section{Sukces przedsiębiorstwa społecznego}

Poziom organizacji i zarządzania to główny czynnik, który decyduje o sukcesie każdej organizacji, także działającej w trzecim sektorze. Umiejętność zbudowania organizacji wokół szansy, a następnie zarządzania nią w sposób efektywny, to zagadnienia, dotyczące nie tylko firm konkurujących ze sobą na rynku sektora prywatnego. Główny cel podejmowanych wysiłków w zarządzaniu organizacją to osiągnięcie sukcesu i zdolność organizacji do rozwoju w długiej perspektywie czasowej (Drucker, 2000, s. 78-84). Współczesne organizacje utraciły trwałość, która do tej pory była cechą gwarantującą bezpieczeństwo ich istnienia, a także funkcjonują w świecie, w którym nie ma stałych reguł. Brakuje także uniwersalnego stylu zarządzania, a co za tym idzie, uniwersalnej recepty na sukces (Skrzypek, 2007, s. 7). Sprawa jest bardziej skomplikowana w przypadku przedsiębiorstw społecznych. Mając na uwadze wymogi dotyczące realizacji celów społecznych, jak i zapewnienia stabilnej sytuacji finansowej i rozwoju przedsiębiorstwa społecznego, można dokonać próby zaprezentowania klasyfikacji przedsięwzięć w kategoriach sukcesów i porażek. Przedstawiona klasyfikacja przedsiębiorstw społecznych opiera się na rozwiązaniu zaproponowanym przez A. Thomasa (2004, s. 253-255), który dokonuje zróżnicowania pomiędzy sukcesem społecznym a ekonomicznym. Odnosząc się do organizacji nienastawionych na zysk można stwierdzić, że sukces przedsiębiorstwa społecznego wymaga osiągnięcia zarówno celów ekonomicznych, jak i społecznych. Brak spełnienia choćby jednego z kryteriów może skutkować porażką w obszarze ekonomicznym lub społecznym.

W ocenie sukcesu osiąganego m.in. przez przedsiębiorstwa społeczne można rozważyć kierowanie się takimi kryteriami, jak (Darby, Jenkins, 2006, s. 423):

- „stopień, do którego przedsięwzięcie społeczne osiąga założone cele,

- zdolność przedsięwzięcia do kontynuacji i trwałości przez zdobywanie zasobów niezbędnych do zapewnienia bieżącej działalności,

- zasoby możliwe do wykorzystania dla rozwoju przedsięwzięcia”.

Jak więc widać, wykorzystywanie stopy zwrotu finansowego jako jedynego wskaźnika sukcesu organizacji non-profit nie jest właściwe, ponieważ konieczne jest uwzględnienie także innych czynników. 
Tabela 1. Przykłady definiowania przedsiębiorstwa społecznego w różnych regionach świata

\begin{tabular}{|c|c|}
\hline Region & Dominująca definicja i jej uzupełnienie \\
\hline Europa & $\begin{array}{l}\text { Przedsiębiorstwo społeczne jest to prywatna i niezależna organizacja dostarczająca dobra } \\
\text { i/lub świadcząca usługi, a jej wyraźnym celem jest przynoszenie korzyści społeczności, } \\
\text { w której funkcjonuje; jest ona własnością lub jest zarządzana przez grupę obywateli } \\
\text { (obywatelską), a istotny interes inwestorów podlega ograniczeniom (UNDP, 2008) } \\
\text { 1. Kryteria ekonomiczne: } \\
\text { - ciągła działalność w zakresie produkcji dóbr i/lub świadczenia usług } \\
\text { - wysoki stopień niezależności (autonomii) } \\
\text { - podejmowanie ryzyka ekonomicznego na znaczącym poziomie } \\
\text { - minimalny poziom zatrudnienia za wynagrodzeniem } \\
\text { 2. Kryteria społeczne: } \\
\text { - wyraźnie zdefiniowany cel, przynoszący korzyści społeczności lub wyróżnionej, } \\
\text { specyficznej grupie ludzi } \\
\text { - inicjatywa pochodząca od grupy obywateli } \text { - zdolność podejmowania decyzji nie oparta na } \\
\text { własności kapitałowej } \\
\text { - partycypacyjny charakter funkcjonowania angażujący osoby (podmioty), których działania dotyczą } \\
\text { - ograniczona dystrybucja zysków (wykluczenie organizacji dążących do maksymalizacji zysków) }\end{array}$ \\
\hline Polska & $\begin{array}{l}\text { Przedsiębiorstwo społeczne to działalność gospodarcza, która wyznacza sobie cele ściśle } \\
\text { społeczne i która inwestuje ponownie nadwyżki zależnie od tych celów w działalność lub } \\
\text { we wspólnotę, zamiast kierować się potrzebą osiągania maksymalnego zysku na rzecz } \\
\text { akcjonariuszy lub właścicieli (Hauser, Laurisz, 2008) } \\
\text { 1. Motywy powstania - przedsiębiorstwo społeczne zostaje powołane do życia z powodu } \\
\text { i dla celów społecznych, w celu realizacji zmiany społeczno-ekonomicznej otoczenia } \\
\text { 2. Misja-realizacjacelów społecznychjestjednoznacznie połączonezmisją przedsiębiorstwa } \\
\text { 3. Podwójny rachunek wartości ekonomiczno-społecznej - przedsiębiorstwa społeczne } \\
\text { dążą do realizacji zysków mających parametry społecznej użyteczności i społecznego } \\
\text { oddziaływania pośredniego i bezpośredniego } \\
\text { 4. Ostateczny cel-priorytetem jest cel społeczny, a osiąganie zysków pełni funkcję pomocniczą }\end{array}$ \\
\hline USA & $\begin{array}{l}\text { Przedsiębiorstwo społeczne jest definiowane jako każde przedsięwzięcie biznesowe stworzone } \\
\text { dla realizacji celu społecznego, którym jest łagodzenie lub zmniejszanie problemu społecznego } \\
\text { bądź też nieprawidłowości w funkcjonowaniu rynku oraz generowanie wartości społecznej } \\
\text { przy jednoczesnym działaniu z zachowaniem dyscypliny finansowej, innowacyjnej postawy } \\
\text { i determinacji właściwej prowadzeniu biznesu w sektorze prywatnym (Alter, 2007) } \\
\text { Cechy: } \\
\text { • cel społeczny - są tworzone w celu generowania wpływu społecznego i zmiany poprzez } \\
\text { rozwiązanie problemu społecznego lub nieprawidłowości w funkcjonowaniu rynku } \\
\text { • podejście przedsiębiorcze - wykorzystują mechanizmy biznesowe, przedsiębiorczość, } \\
\text { innowacje, podejścia rynkowe, orientację strategiczną, dyscyplinę i determinację biznesu } \\
\text { nastawionego na zysk } \\
\text { • społeczna własność-znaciskiem na dobro publiczne i gospodarowanie, choć niekoniecznie } \\
\text { odzwierciedlone w prawnej formie własności. } \\
\text { Przedsiębiorstwo odzyskane (recuperated companies) - firmy, które zostały porzucone przez } \\
\text { ich włásicieli z powodu bankructwa lub defraudacji, a których pracownicy, zorganizowani } \\
\text { głównie w spółdzielnie, kontynuują produkcję lub świadczenie usług w ramach systemu } \\
\text { samorządności (Roitter, Vivas, 2009). } \\
\text { Pojęcie „przedsiębiorstwo społeczne” jest metaforą szczególnego rodzaju aktywności } \\
\text { zarówno firm, jak i organizacji non-profit, która jest ukierunkowana na generowanie wartości } \\
\text { społecznej poprzez kreowanie społecznego zaangażowania związanego z mobilizacją } \\
\text { i odpowiednim przydzielaniem zasobów przedsiębiorstwa na inicjatywy społeczne; } \\
\text { szczególnym przypadkiem przedsiębiorstwa społecznego jest diada podmiotów: firma } \\
\text { i założona przez nią fundacja (Austin, 2006) }\end{array}$ \\
\hline
\end{tabular}




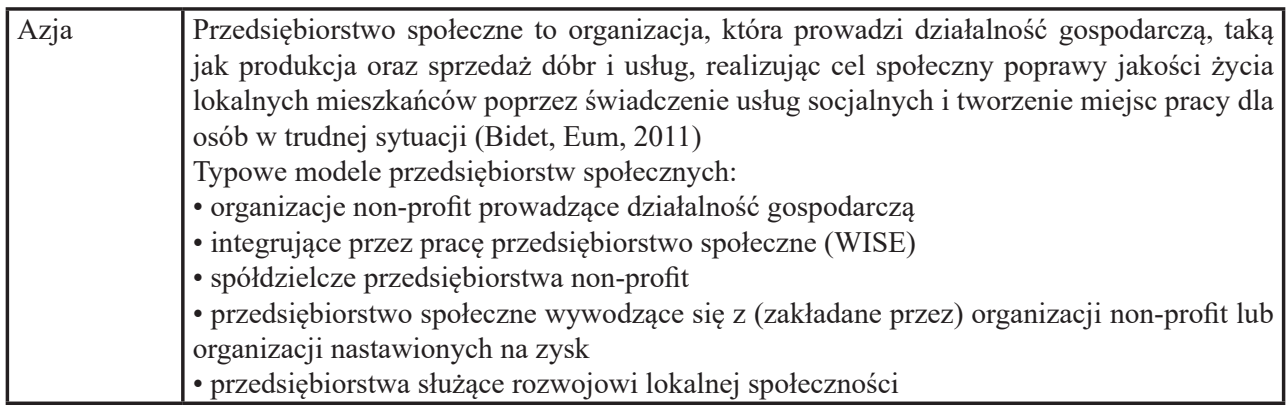

Źródło: opracowanie własne na podstawie: Austin, 2006; Alter, 2007; Hausner, Laurisz, 2008; UNDP, 2008; Roitter, Vivas, 2009; Bidet, Eum, 2011.

\section{Kontekstowe uwarunkowania osiągania sukcesu przedsiębiorstw społecznych}

Ze względu na wagę, aktualność problemów związanych z funkcjonowaniem przedsiębiorstw społecznych oraz ich specyficzne cechy, a zwłaszcza ich niedostateczną orientacją przedsiębiorczą, uzasadnione wydaje się poszukiwanie źródeł sukcesu tych organizacji i dążenie do zidentyfikowania uwarunkowań ich rozwoju (Wronka-Pośpiech, 2017). Dokonując analizy literatury, która podejmuje temat przedsiębiorczości społecznej stwierdza się, że badania głównie skoncentrowane są na identyfikacji rozwiązań warunkujących przetrwanie i nieustanny rozwój organizacji (Hisrich i in., 2000, s. 104). Czynniki te można podzielić na te o charakterze zewnętrznym i wewnętrznym.

\subsection{Uwarunkowania zewnętrzne}

Sukces przedsiębiorstw społecznych jest pochodną trwających przemian społeczno-gospodarczych obserwowanych już od kilku dziesięcioleci w Europie oraz w Stanach Zjednoczonych (Osborne, Gaebler, 2005). Przekształcanie sektora publicznego w krajach europejskich i USA, regularny niedobór środków niezbędnych do zaspokajania stale rosnących potrzeb społecznych, a także rozwój idei społeczeństwa obywatelskiego to tylko niektóre z okoliczności, przyczyniających się do rozwoju przedsiębiorczości społecznej (Kraśnicka, 2002; Frączkiewicz-Wronka, 2009).

W Polsce czynnikami stymulującymi funkcjonowanie organizacji sektora ekonomii społecznej, w tym również przedsiębiorstw społecznych, są procesy transformacji, strukturalna presja wywołana ograniczeniem roli, jaką sprawuje sektor publiczny i przedsiębiorstw po 1989 r. z ich skutkami w postaci stosunkowo wysokiego bezrobocia, wzrostu ubóstwa oraz luki socjalnej w sferze usług społecznych. Ponadto wejście Polski do Unii Europejskiej i możliwość wykorzystania funduszy strukturalnych przeznaczonych na budowanie spójności społecznej uznawane jest dodatkowo za czynnik sprzyjający rozwojowi tego sektora (Grewiński, 2007, s. 117). Wyżej wymienione uwarunkowania dotyczące funkcjonowania przedsiębiorstw społecznych wskazują, że mają one różny charakter: polityczny, ekonomiczny, prawny, instytucjonalny, społeczny, a także historyczny. Ważniejszymi czynnikami 
wpływającymi na osiąganie sukcesu przez przedsiębiorstwa społeczne z pewnością są regulacje prawne, zwłaszcza dotyczące statusu podmiotów ekonomii społecznej, relacja z administracją publiczną oraz źródeł finansowania . Ustawy regulujące działalność podmiotów ekonomii społecznej, w tym przedsiębiorstw społecznych, zasadniczo różnią się pomiędzy państwami, bezpośrednio wpływając na istniejące zróżnicowanie przedsiębiorczości społecznej pomiędzy regionami.

Za kolejny ważny czynnik, który sprzyja funkcjonowaniu sektora ekonomii społecznej uznaję się wsparcie inicjatyw oferowane przez Unię Europejską (Grewiński, 2007, s. 117). Instytucje europejskie (m.in. Komisja Europejska) są aktywnie zaangażowane w rozwój ekonomii społecznej, w tym przedsiębiorstw społecznych. Głównym instrumentem unijnym wspierającym przedsięwzięcia ekonomii społecznej są fundusze strukturalne przeznaczone na budowanie spójności społecznej, a w szczególności Europejski Fundusz Społeczny (EFS) oraz Europejski Fundusz Rozwoju Regionalnego (EFRR) (Spear, 2006, s. 13).

Istotne znaczenie dla ich rozwoju mają również czynniki historyczne i kulturowe, które wywierają decydujący wpływ na kształtowanie mentalności i aktywności społeczeństwa (Grewiński, Karwacki, 2015).

Niewątpliwie czynnikiem silnie oddziałującym na powstawanie i rozwój przedsiębiorstw społecznych jest także dostęp do kapitału finansowego na uruchomienie przedsięwzięcia, a potem wypracowanie środków zapewniających realizację założonych celów bądź też skuteczność w pozyskaniu środków z innych źródeł (np. darowizny).

Posiadanie kapitału finansowego jest nieuniknione dla każdego rodzaju organizacji. W przypadku przedsiębiorstw społecznych, których głównym celem nie jest maksymalizacja zysku, a realizacja zadań społecznych, kapitał finansowy jest niezbędny do powstania i funkcjonowania organizacji.

\subsection{Uwarunkowania wewnętrzne}

Aktualnie przedsiębiorstwa społeczne, podobnie jak inne podmioty działające na rynku, stają przed coraz większymi wyzwaniami, do których można zaliczyć przede wszystkim: dużą zmienność otoczenia, szybko zmieniające się potrzeby i preferencje społeczeństwa, rozwój prywatnej konkurencji w sferze usług społecznych, ograniczenie pomocy finansowej i konieczność pozyskiwania funduszy z innych źródeł oraz problemy z pozyskaniem wolontariuszy (Limański, Drabik, 2007, s. 75).

Niewłaściwe zarządzanie to powód wielu problemów, które w konsekwencji wpływają na wyniki osiągane przez organizacje. Z kolei umiejętność zbudowania organizacji a następnie zarządzania nią w sposób efektywny dotyczy nie tylko firm konkurujących ze sobą na rynku sektora prywatnego (Germak, Singh, 2010). 
Tabela 3. Najważniejsze przesłanki wskazujące na to, że zarządzanie w podmiotach ekonomii społecznej, w tym w przedsiębiorstwach społecznych, będzie dalej podlegać profesjonalizacji

\begin{tabular}{|c|l|}
\hline Lp. & \multicolumn{1}{|c|}{ Przesłanki wskazane przez A. Witek - Crabb (2006, s. 132) } \\
\hline 1. & $\begin{array}{l}\text { Znaczny udział w przychodach organizacji pozarządowych mają środki publiczne, a zatem } \\
\text { administracja publiczna wywiera presję na organizacje non- -profit w zakresie sprawozdawczości } \\
\text { i jakości zarządzania. }\end{array}$ \\
\hline 2. & $\begin{array}{l}\text { Wiele organizacji non-profit funkcjonuje równolegle w sektorze biznesowym. Działalność } \\
\text { gospodarczą w 2015 r. prowadziło 16\% organizacji, a przychody z tego źródła stanowiły średnio } \\
20 \% \text { całości przychodów (w ciągu dwóch lat udział ten wzrósł dwukrotnie). Działalność organizacji } \\
\text { na konkurencyjnym rynku for-profit dodatkowo wymusza profesjonalizację zarządzania. }\end{array}$ \\
\hline 3. & $\begin{array}{l}\text { Pomimo optymistycznej dynamiki sektora (wzrost liczby organizacji) niepokojące jest to, że wiele } \\
\text { organizacji szybko kończy swoją działalność. Wydaje się, że pod tym względem można ten sektor } \\
\text { porównać z sektorem MSP. Charakterystyczna jest też duża rotacja pracowników i wolontariuszy } \\
\text { oraz trudna sytuacja finansowa. Tego rodzaju wyzwania zwracają uwagę na konieczność poprawy } \\
\text { zarządzania. }\end{array}$ \\
\hline
\end{tabular}

Źr ódło: opracowanie własne na podstawie: Witek-Crabb, 2006.

Przedsiębiorstwa społeczne funkcjonują na rynku dóbr i usług a w ich otoczeniu działają różne podmioty, takie jak: instytucje sektora publicznego, organizacje samorządowe i pozarządowe oraz przedsiębiorstwa prywatne. Warto podkreślić, że zasadniczym celem działalności przedsiębiorstw społecznych jest dostarczanie dóbr oraz usług wykraczających poza potrzeby własnych członków (Waligóra, 2018, s. 114). Wszystkie podmioty mogą oferować tego samego rodzaju produkty i usługi, mimo iż, różnią je cele działalności, sposoby finansowania, podejście do zysku, sposób podejmowania decyzji oraz filozofia działania (Battilana, Dorado, 2010).

Dla przedsiębiorstw społecznych cele ekonomiczne są tak samo ważne, jak cele społeczne, ponieważ obok celów społecznych oferują one dobra i usługi. Opisując otoczenie, w jakim funkcjonują przedsiębiorstwa społeczne, warto wymienić płaszczyzny, w których konkurują one z innymi podmiotami. Jak podają M. Goldsmith i in. (2010, s. 81-87), przedsiębiorstwa społeczne walczą o fundusze, personel (włączając wolontariuszy i znane osobistości wspierające ich działalność), użytkowników (klientów) oraz opinię publiczną.

Za ważny czynnik sprzyjający sukcesowi przedsiębiorstw społecznych uznaje się samych przedsiębiorców społecznych. W kontekście osoby przedsiębiorcy społecznego szczególnie ważna jest kwestia przywództwa oraz orientacji przedsiębiorczej.

\section{Typologie czynników decydujących o sukcesie przedsiębiorstw oraz specyfikacja zarządzania przedsiębiorstwem społecznym}

Czynniki sukcesu to przede wszystkim zasoby warunkujące powodzenie organizacji, a do kluczowych zalicza się takie, które przesądzają o konkurencyjnej pozycji organizacji. Według Flores i Fadden (2000, s. 33), są to wszystkie zasoby, kompetencje i umiejętności, które tworzą przewagę konkurencyjną organizacji na danym rynku obecnie i mogą zdecydować o możliwości osiągnięcia przez nią sukcesu w przyszłości (Rockart, 1979). Cechuje je dynamizm, gdyż zmieniają się w zależności od tego, w jakiej sytuacji i w jakim punkcie znajduje się organizacja. Determinują tym samym pola aktywności zarządzających (Meibodi, Mona- 
vvarian, 2010, s. 128) oraz wpływają na realizację misji organizacji (Sharir, Lerner, 2006). W przypadku każdej organizacji, o sukcesie przedsiębiorstwa społecznego decydują różne czynniki związane z organizacją i z jej otoczeniem, które można odnieść do czterech wymiarów: indywidualnego (przedsiębiorcy), otoczenia, organizacji i procesów (Foley, 1985, s. 17-19; Gartner, 1985).

Jedną z pierwszych prób ustalenia czynników i wskaźników sukcesu organizacji non-profit w Polsce podjęła się M. I. Krzelowska (2008, s. 70-73). W efekcie przeprowadzonego w 2006 r. internetowego badania ankietowego, które było skierowane do 210 organizacji pozarządowych mających status organizacji pożytku publicznego zidentyfikowano następujące czynniki sukcesu: pracownicy, wolontariusze, członkowie $(65,2 \%)$; misja organizacji (57,6\%); umiejętność pozyskiwania środków finansowych (51,9\%); wysoka jakość usług (46,2\%); efektywne zarządzanie (29\%), nowoczesność i aktualność oferty (17,6\%); dobrze zorganizowany system informacji $(16,2 \%)$; intensywne działania marketingowe $(12,4 \%)$.

T. Kafel (2009, s. 161) opisuje z kolei przeprowadzone w 2009 r. badania dotyczące kluczowych czynników sukcesu w sektorze usług opiekuńczych. Badaniami zostały objęte wszystkie Zarządy Rejonowe Polskiego Czerwonego Krzyża w Małopolsce.

Według ankietowanych zarządów istotne są kluczowe czynniki:

1) reputacja (image organizacji),

2) dostęp do źródeł finansowania,

3) wysokie kwalifikacje pracowników (wysoka jakość świadczonych usług),

4) możliwość osiągnięcia konsensusu w kontaktach z partnerami,

5) wysoki poziom zarządzania informacjami (komunikacji) - szczególnie w relacjach $\mathrm{z}$ otoczeniem,

6) niskie ceny świadczonych usług,

7) misja organizacji skonstruowana tak, że konsumenci, fundatorzy i społeczność widzą w niej możliwość zaspokojenia swoich potrzeb (akceptacja społeczna),

8) kultura organizacyjna (np. zdolność reagowania na wyzwania, zmiany)

W kolejnych, przeprowadzonych w 2012 r. badaniach wzięło udział 300 respondentów reprezentujących podmioty ekonomii społecznej (w tym przedsiębiorstwa społeczne). Przeprowadzona identyfikacja kluczowych czynników sukcesu, dokonana na podstawie analizy literatury i badań ich dotyczących w sektorze non-profit, pozwoliła na wyodrębnienie 26 potencjalnych czynników, spośród których 10 uznano za kluczowe czynniki zwiększające prawdopodobieństwo sukcesu ekonomicznego i społecznego: (1) przywództwo, (2) motywacja i zaangażowanie ludzi zatrudnionych, (3) sprzyjające rozwiązania prawne, (4) atrakcyjność i innowacyjność oferty, (5) wiedza zarządcza, (6) pozytywne cechy osobiste pracowników mających kontakt z klientem, (7) współpraca z organizacjami sektora publicznego, (8) kapitał społeczny, (9) zaangażowanie społeczności lokalnej oraz (10) utrzymywanie i udostępnianie dokładnych zapisów finansowych (Wronka, 2014). 
Tabela 3. Klasyfikacja przedsiębiorstw społecznych w aspekcie sukcesu i porażki

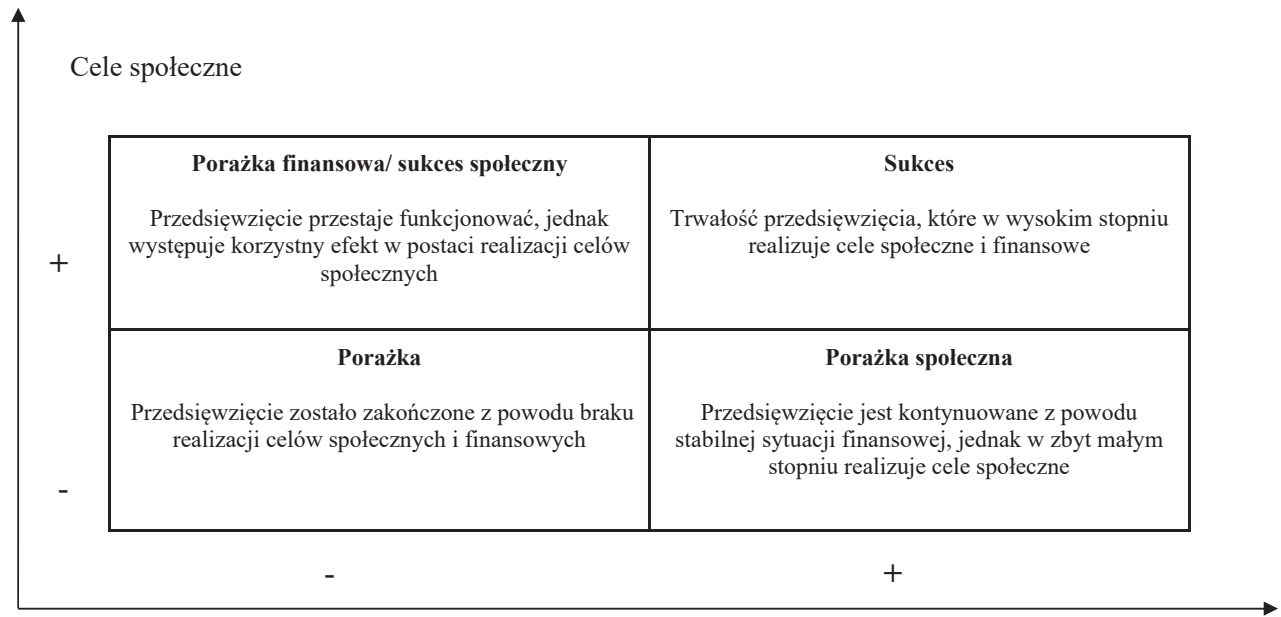

Źr ódło: opracowanie własne na podstawie: Thomas, 2004.

Według sytuacyjnych (zależnościowych) teorii przywództwa (contingency theories) rozwijanych przez takich badaczy, jak m.in. Fiedler (1967), House i Mitchell (1974) czy Vroom i Yetton (1973), istotne jest odpowiednie dopasowanie stylu zarządzania i wzorców przewodzenia do zastanej sytuacji oraz konkretnego kontekstu organizacyjnego (Schmid, 2006). W zawiązku z tym nie można zapominać, że otoczenie, w jakim funkcjonują przedsiębiorstwa społeczne, cechują nie tylko specyficzne wyzwania, szanse, zagrożenia, ale i ograniczenia, z którymi musi sobie poradzić zarządzający.

Wskazuje się na wiele umiejętności, jakie powinny cechować wszystkich menedżerów: podejmują oni decyzje, ustalają cele, tworzą struktury organizacyjne, zatrudniają i motywują pracowników, czyli - nawiązując do funkcji zarządzania - planują, organizują, motywują i kontrolują (Robbins, DeCenzo, 2002, s. 21). Powstaje pytanie, czy przedsiębiorstwa społeczne są na tyle podobne do swoich nastawionych na zysk odpowiedników, że umiejętności te będzie można uogólnić.

W przypadku przedsiębiorstw społecznych struktura organizacyjna jest wyznaczana przez kilka czynników m.in.: - stopień formalizacji organizacji - przedsiębiorstwa społeczne to zwykle struktury mało sformalizowane, które nie posiadają zbyt wielu procedur i przepisów regulujących realizację jego celów i opisujących relacje między pracownikami, - stopień centralizacji (lub decentralizacji) - jako małe organizacje, przedsiębiorstwa społeczne pozostają zwykle organizacjami zdecentralizowanymi, władza nie jest skupiona w jednych rękach, co może powodować zwiększenie wpływu pracowników na podejmowane decyzje, - stopień rozpiętości kierowania - określa liczbę osób podległych kierownikowi w danej organizacji; w przypadku przedsiębiorstw społecznych obserwuje się dużą rozpiętość kierowania, a struktura organizacji jest płaska (Czemiel - Grzybowska, 2010).

Istotą zarządzania jest umiejętność podejmowania decyzji. W klasycznej organizacji działającej w sektorze publicznym czy prywatnym do zadań osoby będącej na stanowisku kierowniczym należy rozwiązywanie problemów związanych z zakresem działania danej jednostki organizacyjnej oraz odpowiedzialność za podejmowane decyzje. W przedsiębiorstwie społecz- 
nym kwestia podejmowania decyzji jest bardziej złożona, ponieważ z założenia członkowie mają takie samo, równe prawo do podejmowania decyzji, a zatem powinny być one podejmowane zespołowo lub w wyniku procesu konsultacji. Oczywiście w wielu przypadkach w przedsiębiorstwie społecznym występuje osoba menedżera, który odpowiadającego za operacyjną działalność organizacji. Można zatem założyć, że decyzje o charakterze strategicznym są podejmowane wspólnie, natomiast prawo do podejmowania decyzji operacyjnych pozostaje w rękach menedżera, jeśli są one zgodne z decyzjami ogółu (Lohmann, 2009, s. 440).

Rozważając zatem cechy charakterystyczne dla procesu zarządzania przedsiębiorstwem społecznym, można je za M. Hudsonem (1997, s. 25-29) określić następująco:

- cele trudne do określenia (trudności w precyzyjnym i mierzalnym określeniu celów, takich jak np. widoczna poprawa zdrowia czy jakości życia),

- problemy z oceną realizacji celów oraz z motywowaniem personelu,

- złożone struktury organizacyjne wynikające z potrzeby pogodzenia interesów interesariuszy, którzy często pełnią rolę decydentów (poprzez zasiadanie w radzie zarządzającej przedsiębiorstwa),

- akcentowanie i pielęgnacja wyznawanych wartości, ponieważ ich lekceważenie osłabia morale zaangażowanych,

- różnorodność motywów determinujących zaangażowanie interesariuszy - od politycznych, poprzez społeczne, edukacyjne, osobiste, filantropijne itp.

\subsection{Zarządzanie zasobami ludzkimi}

Zarządzanie zasobami ludzkimi (ZZL) w literaturze przedmiotu definiowane jest pod różnym kątem. Według M. Amstronga (1996, s. 9) zarządzanie zasobami ludzkimi oznacza „strategiczne, spójne i wszechstronne spojrzenie na problemy związane z kierowaniem i rozwojem zasobów ludzkich w ramach struktur przedsiębiorstw, przy czym każdy aspekt tego procesu stanowi istotny element zarządzania organizacją jako całością". ZZL postrzega ludzi jako najcenniejsze źródło sukcesów firmy i traktuje ich nie jako koszty zmienne, lecz jako majątek trwały, stąd też stoi na stanowisku, iż należy zapewnić jak najlepszych przywódców i możliwości pełnego rozwoju posiadanych zdolności.

Wzrost znaczenia zasobów ludzkich w organizacji to wynik sytuacji, w której kapitał ludzki jest siłą napędową rozwoju i innowacyjności firmy. Możliwości, jakie niesie właściwe zarządzanie zasobami ludzkimi, stwarza warunki do skutecznego zarządzania przedsiębiorstwem przy wyznaczonej misji oraz określonych celach strategicznych firmy.

\subsection{Praktyki zarządzania zasobami w przedsiębiorstwach społecznych}

Jako jeden z filarów efektywnego zarządzania zasobami ludzkimi jest rozwijanie wysoce skutecznych praktyk tworzenia i utrzymania utalentowanego kapitału ludzkiego. Możliwe jest to tylko wówczas, gdy występuje spójność pomiędzy różnymi celami organizacyjnymi, skierowanymi na tworzenie przede wszystkim wartości społecznej. Byłoby sprzecznością, gdyby organizacja z ważnymi ideałami społecznymi nie potrafiła docenić ludzi, którzy w niej funkcjonują. W warunkach sprzyjającym pracownikom i miłym klimacie pracy jest możliwe ich wysokie zaangażowanie i identyfikacja z misją organizacji. 
Praktyką zmniejszającą rotację pracowników, a jednocześnie zwiększającą ich efektywność i siłę więzi z przedsiębiorstwem, jest poziom zgodności między wartościami promowanymi przez organizację a osobistymi wartościami kandydata. Praktyką stosowaną w tym zakresie jest zatrudnianie osób polecanych (rekomendowanych) przez osoby już funkcjonujące w organizacji. Oczekuje się, że z jednej strony polecający dobrze znają swoich krewnych czy też znajomych i dostrzegają ich dopasowanie do organizacyjnego systemu wartości, z drugiej zaś osoby polecane, czując wdzięczność i odpowiedzialność względem rekomendujących, zrobią wiele, aby nie zawieść pokładanego w sobie zaufania.

Przypadkiem często praktykowanym jest zatrudnianie na stałe wolontariuszy, którzy wcześniej mogli pełnić różne zadania, np. koordynować działania innych osób czy promować działania przedsiębiorstwa społecznego. Koniecznie trzeba mieć na uwadze i pamiętać, organizacje te prowadzą mniejszą liczbę szkoleń niż organizacje rynkowe, co wynika z faktu, że przeznaczają znacznie większą część swoich zasobów na przedsięwzięcia społeczne. Dlatego tak ważne w przypadku nowo zatrudnionych osób jest ich „doświadczenie (w pracy) w terenie" oraz monitorowanie efektywności działań, nowo zatrudnionych osób. Również dzięki szkoleniom specjaliści lepiej rozumieją funkcje, jakie realizują, dzięki czemu będą w stanie przygotować propozycje ich udoskonaleń i wdrażać innowacje, których inne organizacje nie dostrzegły.

W przedsiębiorstwach społecznych utrzymywana powinna być stała uwaga na rozwijanie zdolności zarządczych $\mathrm{w}$ zakresie poszerzania swoich umiejętności: na najwyższym poziomie zarządzania, w zakresie ról przywódczych, zarządzania projektami, a także rozwiązywania problemów społecznych. Na początku funkcjonowania przedsiębiorstwa społecznego, przy ograniczonych zasobach, są preferowani kierownicy mający wiedzę i umiejętności z zakresu zarządzania firmą, którzy w trakcie funkcjonowania, poprzez szkolenia i treningi, nabywają wiedzę i umiejętności z obszaru związanego z działaniami społecznymi. Dodatkowo, charakterystyczne jest dzielenie się wiedzą i praktykami pomiędzy kierownikami przedsiębiorstwa społecznego.

Znaczna część organizacji jako fundament retencji pracowniczej postrzega identyfikację pracowników z wartościami organizacji. Inne wdrażają zachęty ekonomiczne w celu zwiększenia lojalności i produktywności personelu. Mechanizm zatrzymywania personelu, aby zapewnić wysoki poziom pracowniczej lojalności wobec organizacji i trwałe więzi z nią, powinien obejmować wiele różnych działan wdrażanych przez przedsiębiorstwo.

W przypadku organizacji non-profit, które funkcjonują jako przedsiębiorstwa społeczne, można wskazać, że konieczne jest tworzenie zespołów składających się z kompetentnych specjalistów z obszaru działań społecznych, którzy będą silnie zaangażować się w realizację misji organizacji. Przedsiębiorstwa te są nastawione na realizację celów społecznych „atrakcyjnych medialnie", mogą one liczyć na wsparcie ze strony innych podmiotów w zakresie dzielenia się wiedzą i delegowania ekspertów z różnorodnych dziedzin. Niezależnie od tego, organizacje non- -profit powinny wzmocnić swoje kompetencje administracyjne w celu m.in. zatrzymania talentów. 


\section{Kompetencje przedsiębiorcy społecznego}

Krytyczna analiza literatury wykazuje, że praca w przedsiębiorstwie społecznym wymaga dużej elastyczności, różnorodnych umiejętności i kwalifikacji, a poziom skomplikowania pełnionych przez menedżerów ról jest znaczny (Eichner, 2009; Mason, 2012). Niektórzy autorzy (Dacin, Dacin, Tracey, 2011) podkreślają, że poważnym wyzwaniem dla osób nimi kierujących jest głównie równoczesna realizacja celów społecznych i finansowych.

Podstawowe zadania przedsiębiorcy społecznego skoncentrowane są na misji społecznej i tworzeniu wpływu społecznego. Zwraca się także uwagę na kwestię motywacji do angażowania się w działalność społeczną. Przykładowo C. Cannon (2000) identyfikuje trzy kategorie osób, które angażują się w działania przedsiębiorstw społecznych:

- osoby posiadające zasoby finansowe i chcące zrobić coś dla społeczeństwa,

- „natchnieni” pracownicy socjalni poszukujący bardziej efektywnych sposobów pracy socjalnej oraz

- absolwenci szkół wyższych mający pomysł na założenie przedsiębiorstwa społecznego.

Część badaczy podkreśla, że przedsiębiorców społecznych cechuje specyficzny rodzaj społeczno-moralnego zaangażowania w swoje działania (Nicholls, Cho, 2006; Shaw i Carter, 2007), współczucie (Miller, Wesley, Williams, 2012), podczas gdy inni zwracają uwagę na altruizm oraz oburzenie i niezgodę na istniejące nierówności i niesprawiedliwość (Dees, 1998b; Yujuico, 2008). Sharir i Lerner (2006) wskazują na potrzebę osobistej rehabilitacji, potrzebę znajdowania rozwiązań $\mathrm{w}$ ekstremalnych sytuacjach na poziomie indywidualnym oraz chęć realizacji zobowiązań wobec społeczności lokalnej.

Znajomość kompetencji wymaganych do zarządzania przedsiębiorstwem społecznym to atut każdej organizacji, szczególnie jeśli dąży ona do uzyskania przewagi konkurencyjnej. Do rozwijania kompetencji przedsiębiorczych może służyć edukacja, w tym między innymi kształcenie na poziomie uniwersyteckim (Popowska, 2018). Jak zauważa T.V. Mumford, M.A. Campion i F.P. Morgeson (2007, s. 154), skupienie się na kompetencjach przywódczych jest ważne co najmniej z dwóch powodów. Po pierwsze akcentuje możliwość lepszego realizowania funkcji kierowniczych, ponieważ wskazuje na potrzebę identyfikowania i rozwijania brakujących kompetencji i umiejętności tak, aby „przywódcy mogli stać się lepszymi przywódcami”. Po drugie pozwala na przesunięcie ostrości od osoby pełniącej funkcje kierownicze do pracy wykonywanej w organizacji. Zamiast zatem dążyć do określenia cech poszczególnych jednostek, nacisk kładzie się na proces zarządzania organizacją oraz na kompetencje, jakich on wymaga.

\section{Zakończenie}

Zarządzanie zasobami ludzkimi w przedsiębiorstwie społecznym to proces bardzo złożony, względem którego ciągle brak jest wyczerpującej wiedzy i wypracowanych, w pełni sprawdzonych narzędzi. Owy obszar wymaga od menedżerów nie tylko poszukiwania przydatnych zasobów wiadomości, lecz także nieustannej obserwacji postaw i zachowań członków organizacji, będących efektem określonych formalnych i nieformalnych działań kierowniczych, oraz właściwym reagowaniu na nie. Jako jedno z najważniejszych ustaleń dotyczących zarządzania zasobami ludzkimi w przedsiębiorstwach społecznych uznaje się 
wskazanie zdolności tego typu organizacji do wprowadzania innowacyjnych polityk, które nie wymagają zainwestowania znacznych zasobów, ale odzwierciedlają skłonność organizacji do wartościowania (doceniania) osób, z którymi współpracują i działają, oraz dążenie do rozwijania swoich kompetencji tak, aby wkład tych osób ulegał zwiększeniu (ulepszeniu) (Austin, 2006). Z całą pewnością można stwierdzić, iż organizacje społeczne, które opracowują ambitne i wartościowe strategie oraz które podchodzą z należytą starannością do każdego z elementów procesu zarządzania zasobami ludzkimi i integrują je w spójny system, mają nie potwierdzoną oraz nieoficjalną, ale jednak gwarancję posiadania lojalnych, wysoce kompetentnych, ciągle uczących się i zaangażowanych w sprawy społeczne pracowników.

\section{Bibliografia}

Alter, K. (2007). Social Enterprise Typology. Virtue Ventures LLC.

Amstrong, M. (1996). Zarządzanie zasobami ludzkimi. Strategia i działanie. Kraków: Wydawnictwo Profesjonalnej Szkoły Biznesu. ISBN 8385441158.

Austin, J. (ed.) (2006). Effective Management of Social Enterprises. Lessons from Businesses and Civil Society Organizations in IberoAmerica. Cambridge: Harvard University. ISBN 9780674021235.

Battilana, J., Dorado, S. (2010). Building Sustainable Hybrid Organizations: The Case of Commercial Microfinance Organizations. Academy of Management Journal, 6(53), 1419-1440. DOI: 10.5465/ AMJ.2010.57318391.

Bidet, E., Eum, H. S. (2011). Social Enterprise in South Korea: History and Diversity. Social Enterprise Journal, 7(1), 69-85. ISBN 9780804846394.

Cannon, C. (2000). Charity for Profit: How the New Social Entrepreneurs Are Creating Good by Sharing Wealth. National Journal, 16, 1898-1904. DOI: 10.13140/RG.2.2.27697.99683.

Dacin, M. T., Dacin, P. A., Tracey, P. (2011). Social Entrepreneurship: A Critique and Future Directions. Organization Science, 22(5), 1203-1213. DOI: 10.1287/orsc.1100.0620.

Darby, L., Jenkins, H. (2006). International Journal of Social Economics. Applying Sustainability Indicators to the Social Enterprise Business Model, 33(5/6), 411-431. DOI: 10.1108/03068290610660689.

Drucker, P. (2000). Zarządzanie w XXI wieku. Warszawa: Wydawnictwo Muza S.A. ISBN 8372006059.

Flores, L. G., Fadden, J. (2000). How to Have a Successful Strategic Planning Meeting. Training \& Development, 54(1), 31-35.

Foley, M. R. (1985). What Makes a Small Business Successful? Sheffield: Sheffield Centre for Environmental Research. ISBN 9780896216624.

Frączkiewicz-Wronka, A. (red.). (2009). Zarzadzanie publiczne-elementy teorii i praktyki, Katowice: Uniwersytet Ekonomiczny. ISBN 9788372464583.

Germak, A. J., Singh, K. K. (2010). Social Entrepreneurship: Changing the Way Social Workers Do Business. Administration in Social Work, 34(1), 79-95. DOI: 10.1080/03643107.2013.828000.

Goldsmith, M., Greenberg, C. L., Robertson, A., Hu-Chan, M. (2010). Globalni liderzy-kolejna generacja. Warszawa: MT Biznes. ISBN 9788361732877.

Grewiński, M. (2007). Od państwa opiekuńczego do wielosektorowości w kształtowaniu dobrobytu społecznego - zmieniających się kontekst polityki społecznej w Polsce. W: A. Rączaszek, W. Koczur (red.). Polityka społeczna w życiu społecznego gospodarczym kraju. Kraków: Wydawnictwo Akademii Ekonomicznej. ISBN 9788372468932.

Grewiński, M., Karwacki, A. (red.). (2015). Innowacyjna polityka społeczna. Warszawa: WSP im. J. Korczaka. ISBN 9788361121954.

Hausner, J., Laurisz, N. (2008). Czynniki krytyczne tworzenia przedsiębiorstw społecznych. Przedsiębiorstwo społeczne. Konceptualizacja. W: J. Hausner (red.). Przedsiębiorstwa społeczne w Polsce. Teoria i praktyka. Kraków: Uniwersytet Ekonomiczny w Krakowie-Małopolska Szkoła Administracji Publicznej, 9-32. ISBN 9788389410412.

Hisrich, R. D., Freeman, E., Standly, A. R., Yankey, J. A., Young D. R. (2000). Entrepreneurship in the Not-for-Profit Sector. W: D.L. Sexton, R.W. Smilor (red.). Entrepreneurship. Chicago. 
House, R. J., Mitchell, T. R. (1974). Path-goal Theory of Leadership. Journal of Contemporary Business, 3, 81-9. DOI: 10.20935/AL748.

Hudson, M. (1997). Bez zysków i strat. Sztuka kierowania organizacjami sektora pozarządowego. Warszawa: Civic Dialogue Programme Phare. ISBN 9788390673950.

Kafel, T. (2009). Mierniki sukcesu organizacji pozarządowych. W: R. Rutka, P. Wróbel (red.). Sukces organizacji. Istota, pomiar, uwarunkowania. Sopot: Wydział Zarządzania Uniwersytetu Gdańskiego. ISBN: 9788320820058.

Kraśnicka, T. (2002). Koncepcja rozwoju przedsiębiorczości ekonomicznej i pozaekonomicznej. Katowice: Wydawnictwo Akademii Ekonomicznej im. K. Adamieckiego. ISBN 9788372460950.

Krzelowska, M. I. (2008). Sukces organizacji pożytku publicznego w świetle badań. Trzeci Sektor, 13, 68-75.

Limański, A., Drabik, I. (2007). Marketing w organizacjach non-profit. Warszawa: Wydawnictwo Difin. ISBN 9788372517173.

Lohmann, R. A. (2009). Charity, Philanthropy, Public Service, or Enterprise: What Are the Big Questions of Nonprofit Management Today? Public Administration Review, 67(3), 437-444. DOI: 10.1016/j. aos.2008.03.002.

Meibodi, L., Monavvarian, A. (2010). Recognizing Critical Success Factors to Achieve the Strategic Goals of SAIPA Press. Business Strategy Series, 11(2), 124-133. DOI: 1108/17515631011026443.

Miller, T. L., Wesley, C. L., Williams, D. E. (2012). Educating the Minds of Caring Hearts: Comparing the Views of Practitioners and Educators on the Importance of Social Entrepreneurship Competencies. Academy of Management Learning \& Education, 11(3), 349-370. DOI: 10.5465/amle.2011.0017.

Mumford, T. V., Campion, M. A., Morgeson, F. P. (2007). The Leadership Skills Strataplex: Leadership Skill Requirements across Organizational Levels. The Leadership Quarterly, 18, 154-166. DOI: 10.5465/ AMBPP.2003.13792974.

Nicholls, A., Cho, A. (2006). Social Entrepreneurship: The Structuration of a Field. W: A. Nicholls (ed.). Social Entrepreneurship: New Paradigms of Sustainable Social Change. Oxford: Oxford University Press. ISBN ISBN 0199283877.

Osborne, D., Gaebler, T. (2005). Rządzić inaczej. Jak duch przedsiębiorczości przenika i przeksztatca administrację publiczna. Wydanie 2. Poznań: Wydawnictwo Media Rodzina. ISBN 83-7278-150-8.

Popowska, M. (2018). Przedsiębiorczość społeczna jako klucz do skutecznej edukacji przedsiębiorczej na społecznie odpowiedzialnym uniwersytecie. Horyzonty Wychowania, 17(42), 205-219. DOI: 10.17399/ HW.2018.174216.

Robbins, S. P., DeCenzo, D. A. (2002). Podstawy zarzadzania. Warszawa: Polskie Wydawnictwo Ekonomiczne. ISBN 8320813735.

Rockart, J. F. (1979). Chief Executives Define Their Own Data Needs. Harvard Business Review, 57(2), 81-93.

Roitter, M. M., Vivas, A. (2009). Argentina. In: J.A. Kerlin (ed.). Social Enterprise. A Global Comparison. Hannover-London: University Press of New England, 139-162. ISBN 9781584657897.

Sharir, M., Lerner, M. (2006). Gauging the Success of Social Ventures Initiated by Individual Social Entrepreneurs. Journal of World Business, 41(1), 6-20. DOI: 13552550810897696.

Skrzypek, E. (2007). Kapitał intelektualny jako podstawa sukcesu w społeczeństwie wiedzy. Problemy Jakości, 1, 4-7.

Spear, R. (2006). Ramy instytucjonalne dla przedsiębiorstwa społecznego: wyzwania dla Polski i innych nowych krajów członkowskich [online, dostęp: 2021-06-20]. Dostępny w Internecie: http://www.owes.info. pl/biblioteka/14_spear_przedsiebiorstwo_spoleczne.pdf

Thomas, A. (2004). The Rise of Social Cooperatives in Italy. International Journal of Voluntary and Nonprofit Organizations, 15(3), 243-263. DOI: 10.1023/B:VOLU.0000046280.06580.d8.

UNDP. (2008). Social Enterprise: A New Model for Poverty Reduction and Employment Generation. An Examination of the Concept and Practice in Europe and the Commonwealth of Independent States. Regional Bureau for Europe and the Commonwealth of Independent States [online, dostęp: 2021-06-20]. Dostępny w Internecie: https://www.academia.edu/5159946/Social_Enterprise_A_new_model_for_poverty_reduction_and_employment_generation_An_examination_of_the_concept_and_practice_in_Europe_and_the_Commonwealth_of_Independent_States_Social_Enterprise_A_new_model_for_poverty_reduction_and_employment_generation.

Waligóra, A. (2018). Potencjał przedsiębiorczości społecznej w turystyce. Studia Oeconomica Posnaniensia, 6(10), 114-115. DOI: 10.18559/SOEP.2018.10.7 